\title{
Evaluasi Penggunaan Antibiotik Secara Kualitatif di RS Penyakit Infeksi Sulianti Saroso, Jakarta
}

\author{
Sri Sulastri Katarnida, Dewi Murniati, Yusticia Katar \\ SMF Anak RSPI. Sulianti Saroso, Jakarta
}

\begin{abstract}
Latar belakang. Penggunaan antibiotik untuk populasi anak perlu memperoleh perhatian khusus karena kecenderungan berlebihan. Peningkatan penggunaan antibiotik telah menimbulkan peningkatan resistensi bakteri, meningkatkan morbiditas dan mortalitas serta biaya pengobatan, akhirnya menurunkan kualitas pelayanan kesehatan. Salah satu cara mengatasinya dengan melakukan evaluasi penggunaan antibiotik secara kualitatif.

Tujuan. Melakukan evaluasi penggunaan antibiotik di ruang perawatan anak RS Penyakit Infeksi Sulianti Saroso secara kualitatif menggunakan alur Gyssens.

Metoda. Telah dilakukan penelitian deskriptif, retrospektif dari status rekam medis pasien anak nonbedah, yang mendapat antibiotik dan dirawat di ruang Melati RSPIi Sulianti Saroso pada periode tahun 2010. Evaluasi dilakukan menggunakan alur Gyssens dan penghitungan diolah dengan program SPSS versi 19.0.

Hasil penelitian. Di antara 619 (41,7\%) subjek penelitian yang mendapat antibiotik, terbanyak kelompok bayi umur 1 bulan-1 tahun 234 (37, 8\%). Penggunaan antibiotik secara tepat $338(40,9 \%)$, tidak tepat 362 $(43,8 \%)$ dan tidak berdasarkan indikasi 119 (14,4\%). Penggunaan antibiotik secara empirik $821(99,4 \%)$, terapi definitif $4(0,5 \%)$ dan terapi profilaksis $1(0,1 \%)$. Antibiotik yang paling banyak digunakan sefotaksim $308(37,3 \%)$, seftriakson 189 (22,9\%) dan kloramfenikol 131 (15,9\%). Sefotaksim digunakan secara tepat 106 (34,4\%), tidak tepat $144(46,8 \%)$ dan tanpa indikasi 55 (17,9\%).

Kesimpulan. Dari semua pasien anak yang dirawat dan mendapat antibiotik, penggunaan antibiotik secara tepat $40,9 \%$, pemberian tidak tepat $43,8 \%$, dan pemberian tanpa indikasi $14,4 \%$. Sebagian besar terapi secara empirik $99,4 \%$, terapi definitif hanya $0,4 \%$. Sefotaksim paling banyak digunakan, sebagian besar digunakan tidak tepat 46,8\%. Sari Pediatri 2014;15(6):369-76.
\end{abstract}

Kata kunci: evaluasi kualitatif antibiotik, anak, alur Gyssens

Alamat korespondensi:

Dr. Sri Sulastri Katarnida Sp.A, SMF Anak RSPI. Prof. Dr. Sulianti Saroso, Jl. Sunter Permai Raya, Sunter 14340 Jakarta Utara. Telp. (021) 4895279, Fax. (021) 4718778. E-mail: srilastri07@yahoo.co.id

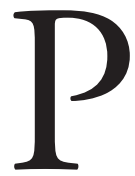
enggunaan antibiotik menjadi kebiasaan rutin untuk pengobatan penyakit infeksi anak. Antibiotik untuk populasi anak perlu memperoleh perhatian khusus karena 
kecenderungan pemakaian yang berlebihan. Populasi anak merupakan golongan umur yang kurang mempunyai data tentang penggunaannya karena jarang dilakukan uji klinik seperti terhadap orang dewasa. ${ }^{1}$

Di negara maju 13\%-37\% dari seluruh pasien yang dirawat di rumah sakit mendapatkan antibiotik baik secara tunggal maupun kombinasi, sedangkan di negara berkembang pemakaiannya 30\%-80\%. Pada penelitian Satari dkk, ${ }^{2}$ di ruang rawat Departemen Ilmu Kesehatan Anak RSUPN Ciptomangunkusumo, dilaporkan penggunaan antibiotik pada $49,2 \%$ subjek penelitian. Beberapa penelitian di negara maju dilaporkan lebih dari duapertiga penggunaan antibiotik tidak rasional tanpa bukti adanya infeksi. ${ }^{3}$ Penelitian AMRIN STUDY ${ }^{4}$ tahun 2005, di Surabaya, ditemukan 45\%-76\% tidak ada indikasi penggunaan antibiotik, sedangkan di Semarang dilaporkan 56\%$76 \%$. Sedangkan pada sebuah kajian rasionalitas penggunaan antibiotik di ICU RSUP Dr Kariadi Semarang periode Juli-Desember 2009 ditemukan ketidaksesuaian penggunaan antibiotik baik secara kuantitas maupun kualitas.

Penggunaan antibiotik rasional adalah penggunaan antibiotik yang sesuai dengan diagnosis penyakit, ketentuan pemilihan yang tepat sehingga tepat sasaran dengan efek samping sangat minimal. ${ }^{5}$ Penggunaan antibiotik berdasarkan indikasi adalah penggunaan antibiotik yang mempunyai manfaat bagi pasien dengan pemberian secara profilaksis dan pemberian terapeutik. Pemberian profilaksis adalah penggunaan antibiotik pada keadaan tidak ada atau belum terdapat gejala infeksi, untuk mencegah infeksi pada pasien yang mempunyai risiko terjadi infeksi bakteri. Pemberian antibiotik secara terapeutik apabila antibiotik digunakan pada keadaan infeksi. Pemberian antibiotik secara terapeutik, dapat dilakukan secara empiris dan definitif. Terapi empiris adalah pemberian antibiotik pada keadaan infeksi sebelum didapat hasil kultur bakteri dan uji kepekaan terhadap antibiotik. Terapi definitif dilakukan berdasarkan hasil biakan bakteri dan uji kepekaan bakteri terhadap antibiotik.

Dalam memilih terapi empiris, harus dipertimbangkan, 1) Tempat infeksi dan organisme yang paling mungkin berkoloni disana. 2) Pengetahuan sebelumnya dari bakteri yang diketahui berkoloni pada pasien tertentu (misalnya skrining apusan hidung yang dilakukan rutin pada beberapa rumah sakit mengindikasikan bahwa pada pasien tertentu berkoloni bakteri MRSA). 3) Pola resistensi bakteri lokal atau antibiogram yang tersedia untuk bakteri penting pada kebanyakan rumah sakit.

Setelah hasil biakan dan uji sensitivitas ada, setiap usaha harus dilakukan untuk mempersempit spektrum antibiotik yang diberikan, ini merupakan komponen penting dalam pemberian antibiotik karena bisa mengurangi toksisitas, mencegah resistensi terhadap antibiotik dan mengurangi biaya pengobatan. ${ }^{6}$

Lebih dari 50\% negara-negara di dunia tidak menerapkan kebijakan dasar untuk mempromosikan penggunaan obat yang rasional. Di negara berkembang kurang dari $40 \%$ pasien di sektor publik dan 30\% swasta yang terapi dilakukan sesuai dengan pedoman klinis. ${ }^{7}$ Dampak negatif penggunaan antibiotik yang tidak rasional adalah timbul dan berkembang bakteri kebal antibiotik sehingga meningkatkan kesakitan dan kematian, pengobatan menjadi lebih mahal yang akhirnya menurunkan kualitas pelayanan kesehatan. ${ }^{8-10}$

Resistensi antibiotik menjadi masalah global dan serius, kejadiannya meningkat di seluruh dunia dan ini harus ditanggulangi bersama. Salah satu cara mengatasinya adalah dengan menggunakan antibiotik secara rasional, melakukan monitoring dan evaluasi penggunaan antibiotik. Baik dilakukan di rumah sakit, maupun di Pusat Kesehatan Masyarakat secara sistematis, terstandar dan teratur, serta melakukan intervensi untuk mengoptimalkan penggunaan antibiotik. ${ }^{7.11}$ Badan Kesehatan Dunia WHO menyarankan untuk meningkatkan penggunaan obat rasional dengan cara, 1) melakukan monitor penggunaan obat dan kebijakan farmasi, 2) menyediakan petunjuk kebijakan dan menyokong untuk melakukan monitor penggunaan obat, mengimplementasi dan evaluasi strategi nasional untuk meningkatkan penggunaan rasional obat. 3) mengembangkan dan memberi program-program pelatihan tenaga profesional kesehatan secara nasional dalam hal melakukan monitor dan memperbaiki penggunaan obat pada semua level dan sistim kesehatan. ${ }^{10}$

Evaluasi penggunaan antibiotik dapat dilakukan dengan dua metode yaitu secara kuantitatif dan kualitatif. Evaluasi antibiotik secara kualitatif dilakukan dengan menilai ketepatan penggunaan antibiotik dengan menggunakan alur Gyssens. ${ }^{12}$ Berdasarkan alur Gyssens, penggunaan antibiotik diklassifikasikan dalam 6 kategori, yaitu kategori I. penggunaan tepat, IIa. tidak tepat dosis, IIb. tidak tepat interval, IIc. tidak tepat rute, IIIa. tidak tepat karena terlalu lama, IIIb. tidak tepat karena terlalu singkat, IVa. tidak tepat 
karena ada antibiotik lain yang lebih efektif, IVb. tidak tepat karena ada antibiotik lain yang lebih aman, IVc. tidak tepat karena ada yang lebih murah, IVd. tidak tepat karena ada spektrum yang lebih sempit, $\mathrm{V}$. tidak ada indikasi antibiotik, VI. catatan rekam medis tidak lengkap untuk dievaluasi (gambar1). Pemberian antibiotik tepat apabila evaluasi sesuai dengan kategori I, pemberian antibiotik tidak tepat apabila antibiotik termasuk kategori IIa, IIb, IIc, IIIa, IIIb, IVa, IVb, IVc, IVd (II,III, IV).

Sampai saat ini evaluasi penggunaan antibiotik pada pasien anak di RSPI Sulianti Saroso belum pernah dilakukan. Tujuan penelitian untuk melakukan evaluasi penggunaan antibiotik pada pasien anak yang dirawat di RSPI Sulianti Saroso secara kualitatif menggunakan alur Gyssens.

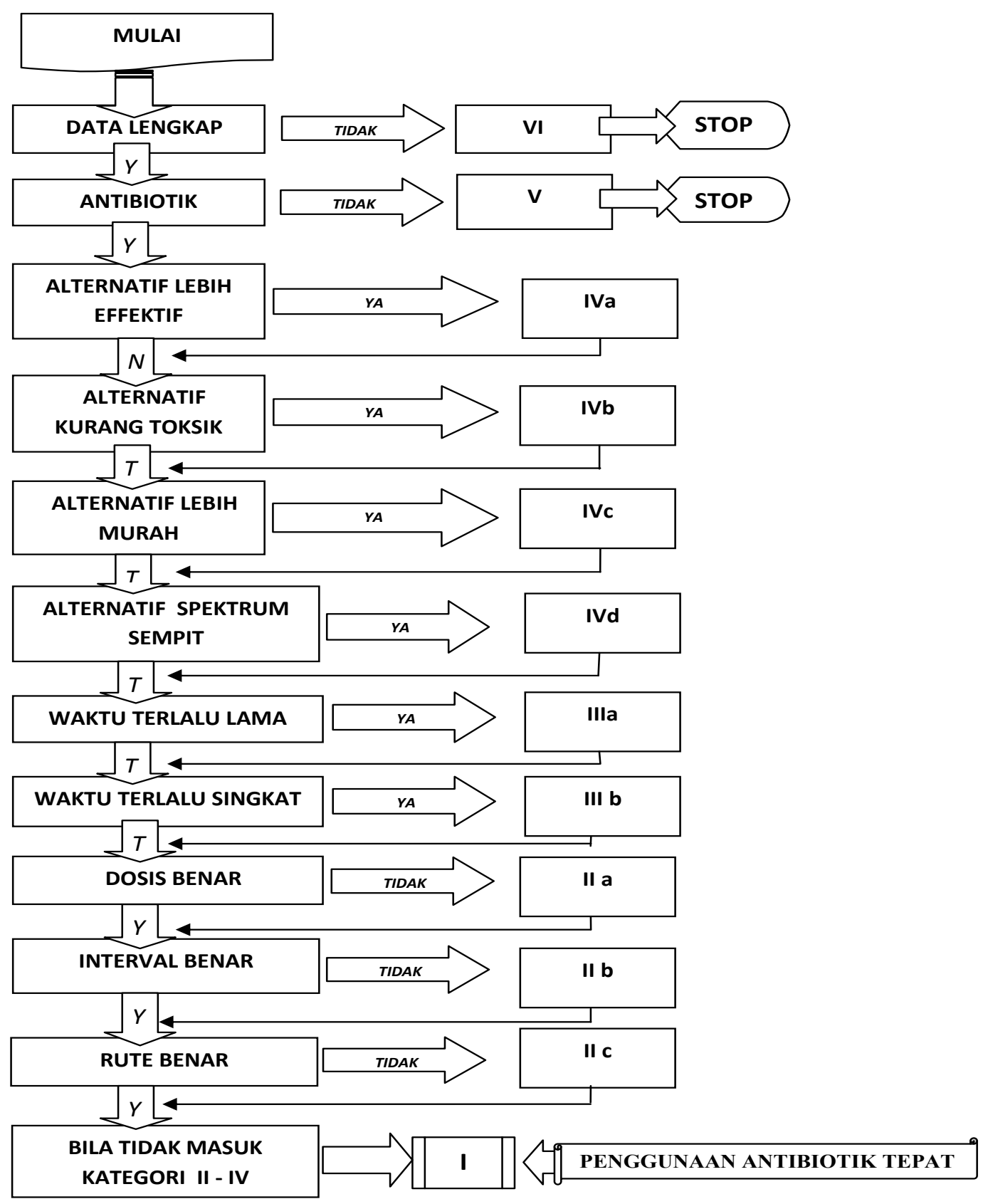

Gambar 1. Alur Gyssens 


\section{Metode}

Penelitian deskriptif retrospektif telah dilakukan dengan mempergunakan data dari status rekam medis pasien anak yang dirawat di ruang rawat Melati kelas I,II,III, ruang isolasi dan ruang High Care Unit RSPI Sulianti Saroso pada tahun 2010. Subjek penelitian adalah semua pasien anak non bedah, umur antara 1 bulan sampai 15 tahun yang dapat antibiotik. Kriteria eksklusi adalah pasien selama perawatan tersebut pernah dirawat di ruang PICU, pasien yang mendapat antibiotik topikal, dan hanya mendapat obat anti tuberkulosis. Data semua pasien diambil dari register rawat inap ruang Melati. Data pasien yang mendapat antibiotik yang berumur 1 bulan sampai 15 tahun, yang diperoleh data dari register Panitia Pengendalian Infeksi Nosokomial. Data dimasukkan dalam dua formulir yang mencatat identitas pasien termasuk (jenis kelamin, umur), lama rawat, diagnosis, antibiotik yang digunakan (dosis, frekuensi atau interval, rute, dan lama pemberian). Formulir ke-3 digunakan untuk melakukan evaluasi terhadap penggunaan antibiotik. Evaluasi penggunaan antibiotik dilakukan untuk semua antibiotik yang digunakan selama dirawat, bukan dari jumlah pasien yang menjadi subjek penelitian dan kami mempercayai diagnosis yang tercantum dalam status rekam medis.

Kriteria penilaian evaluasi antibiotik menggunakan alur Gyssens dan penghitungan dilakukan dengan menggunakan SPSS versi 19.0.

\section{Hasil}

Di antara 1485 pasien anak non-bedah yang dirawat, terdapat 634 orang yang mendapat antibiotik. Sembilan status rekam medis pasien yang menggunakan antibiotik tidak bisa ditemukan sehingga tinggal 625 yang didigunakan. Didapatkan enam pasien tidak diikut sertakan, terdiri dari tiga pasien pernah dirawat di PICU, dua pasien hanya mendapat OAT saja dan satu pasien mendapat antibiotik topikal, sehingga 619/1485 (41,7\%) pasien sebagai subjek penelitian.

Subjek penelitian terdiri dari anak laki 357 $(57,7 \%)$ dan anak perempuan 262 (42,3\%). Distribusi umur bayi 1 bulan $-<1$ tahun mendapat antibiotik 234 $(37,8 \%)$, kelompok umur $1-<3$ tahun $174(28,1 \%)$, umur $3-<5$ tahun 68 (10,9\%), dan kelompok umur
Tabel1. Distribusi lima penyakit terbanyak.

\begin{tabular}{lc}
\hline Diagnosis & Jumlah \\
\hline Gastroenteritis & 178 \\
Demam tifoid & 100 \\
Bronkopnemonia & 66 \\
ISPA & 57 \\
ISK & 37 \\
\hline Jumlah & 438 \\
\hline
\end{tabular}

5-15 tahun $143(23,1 \%)$. Rata-rata umur pasien adalah 5 tahun dengan rentangan umur antara 1.5 bulan sampai 14 tahun.

Lama rawat pasien $\leq 3$ hari $345(55,7 \%)$, dirawat 4-5 hari $137(22,1 \%)$ dan di atas 5 hari 137 (22,1\%). Rata-rata lama rawat pasien adalah 3,7 hari dengan rentangan lama rawat 1 sampai 18 hari.

Distribusi penyakit anak non-bedah adalah gastroenteritis 178, demam tifoid 100, bronkopnemonia 66, ISPA 57 dan ISK 37 orang (tabel 1).

Ditemukan 17 jenis antibiotik yang digunakan, dengan total penggunaan 826 , (terdapat pasien yang mendapat lebih dari satu jenis antibiotik dalam waktu bersamaan). Rata-rata 1,3 antibiotik per perawatan anak di ruang Melati. Antibiotik yang paling banyak diberikan adalah sefotaksim 308 (37,3\%), seftriakson 189 (22,9\%), kloramfenikol 131 (15,9\%).

Di antara 826 antibiotik yang digunakan, 338 $(40,9 \%)$ pemakaian antibiotik tepat (kriteria I), penggunaan antibiotik tidak tepat (kriteria IIa, b, c, IIIa, b, IVa, b, c, d) 362 (43,8\%), 119 (14,4\%) penggunaan antibiotik yang tidak berdasarkan indikasi (kriteria V) dan $7(0,8 \%)$ tidak cukup data rekam medis untuk dievaluasi (kriteria VI).

Hasil penggunaan 826 antibiotik menurut alur Gyssens adalah pemakaian antibiotik tepat $40,9 \%$, penggunaan antibiotik tidak tepat $43,8 \%$, penggunaan antibiotik yang tidak berdasarkan indikasi 14,4\% dan tidak cukup data rekam medis untuk dievaluasi 0,8\% (Gambar 2).

Pada 308 penggunaan sefotaksim, pemberian antibiotik yang tidak tepat 144 (46,7\%), lebih banyak dari pada penggunaan antibiotik tepat 106 (34,4\%). Penggunaan antibiotik tidak tepat terutama karena lama pemberian obat yang terlalu pendek $70(22,7 \%)$ sesuai dengan kriteria Gyssens IIIb dan tidak tepat karena tidak ada indikasi 55 (17,9\%) sesuai dengan kriteria Gyssens V. Pada 189 penggunaan seftriakson, penggunaan tepat $88(46,6 \%)$ dan penggunaan 
Tabel 2, Penggunaan antibiotik menurut alur Gyssens

\begin{tabular}{lccccccccccccccc}
\hline \multirow{2}{*}{ Antibiotik } & I & \multicolumn{1}{c}{ II } & \multicolumn{1}{c}{ III } & \multicolumn{1}{c}{ IV } & \multirow{2}{*}{ V } & VI & Jumlah & $\%$ \\
\hline Cefotaksim & 106 & 7 & 1 & 0 & 3 & 70 & 28 & 1 & 33 & 1 & 55 & 3 & 308 & 37,3 \\
Ceftriakson & 88 & 4 & 1 & 0 & 3 & 43 & 5 & 0 & 20 & 1 & 23 & 1 & 189 & 22,9 \\
Kloramfenikol & 66 & 6 & 17 & 0 & 3 & 16 & 11 & 0 & 1 & 0 & 10 & 1 & 131 & 15,9 \\
Kotrimoksazol & 18 & 0 & 0 & 0 & 0 & 5 & 14 & 1 & 0 & 0 & 12 & 2 & 52 & 34,6 \\
Amoksisilin & 16 & 0 & 2 & 0 & 1 & 6 & 7 & 0 & 0 & 0 & 7 & 0 & 39 & 4,7 \\
Gentamisin & 8 & 0 & 0 & 0 & 0 & 6 & 9 & 0 & 0 & 0 & 2 & 0 & 25 & 3 \\
Ampisilin & 11 & 0 & 0 & 0 & 0 & 5 & 2 & 0 & 0 & 0 & 3 & 0 & 21 & 2,5 \\
Cefiksim & 10 & 0 & 1 & 0 & 0 & 0 & 0 & 0 & 3 & 1 & 3 & 0 & 18 & 2,2 \\
Metronidazol & 9 & 0 & 0 & 0 & 0 & 0 & 2 & 0 & 0 & 1 & 2 & 0 & 14 & 1,7 \\
Tetrasiklin & 1 & 0 & 0 & 0 & 1 & 1 & 4 & 1 & 0 & 0 & 0 & 0 & 8 & 1 \\
Meropenem & 2 & 1 & 0 & 0 & 0 & 0 & 0 & 0 & 3 & 0 & 0 & 0 & 6 & 0,7 \\
Cefadroksil & 2 & 1 & 0 & 0 & 0 & 1 & 2 & 0 & 0 & 0 & 1 & 0 & 6 & 0,7 \\
Tiamfenikol & 0 & 1 & 0 & 0 & 0 & 3 & 0 & 0 & 0 & 0 & 1 & 0 & 5 & 0,6 \\
Eritromisin & 0 & 1 & 0 & 0 & 0 & 0 & 0 & 0 & 0 & 0 & 0 & 0 & 1 & 0,1 \\
Amikasin & 1 & 0 & 0 & 0 & 0 & 0 & 0 & 0 & 0 & 0 & 0 & 0 & 1 & 0,1 \\
Penisilin Prokain & 1 & 0 & 0 & 0 & 0 & 0 & 0 & 0 & 0 & 0 & 0 & 0 & 1 & 0,1 \\
Kanamisin & 0 & 0 & 0 & 0 & 0 & 0 & 1 & 0 & 0 & 0 & 0 & 0 & 1 & 0,1 \\
\hline Jumlah & 338 & 21 & 22 & 0 & 11 & 156 & 85 & 3 & 60 & 4 & 119 & 7 & 826 & 100 \\
\hline
\end{tabular}

tidak tepat lebih sedikit 77 (40,7\%), tanpa indikasi $23(12,2 \%)$. Sedangkan pada 131 penggunaan kloramfenikol, penggunaan antibiotik tepat lebih banyak 66 (50,4\%), dibandingkan yang penggunaan tidak tepat $54(41,2 \%)$ dan pemberian tanpa indikasi $10(7,6 \%)$ (gambar 3).

Tidak semua pasien yang mendapat antibiotik dilakukan pemeriksaan kultur, tercatat 170 (26,8\%), dan ditemukan tumbuh bakteri 42 (24,72\%). Bakteri terbanyak adalah E.coli 8 (19\%), S.epidermidis 7
(16,7\%), Klebsiela 6 (14,3\%). S.typhi 5 (11,9\%), Proteus 4 (9,5\%) dan bakteri lainnya 12.

Di antara 826 terapi antibiotik yang digunakan, $821(99,4 \%)$ antibiotik diberikan secara empiris, satu antibiotik $0,1 \%$ diberikan secara profilaksis, sedangkan pemberian secara definitif hanya $4(0,5 \%)$ antibiotik. Terapi definitif pada empat pasien dengan hasil dua antibiotik pada hasil kultur dan uji kepekaan, bakteri sensitif dengan antibiotik pertama tetapi dalam perkembangan klinis tidak terlihat perbaikan yang

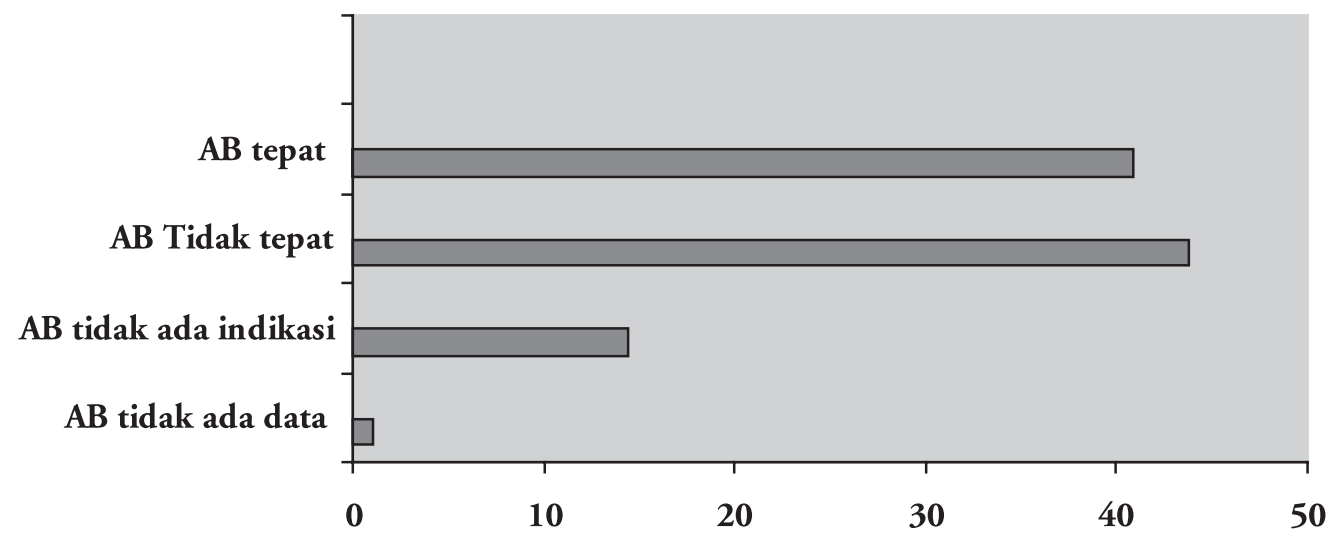

Gambar 2. Evaluasi kualitatif penggunaan antibiotik berdasarkan alur Gyssens 


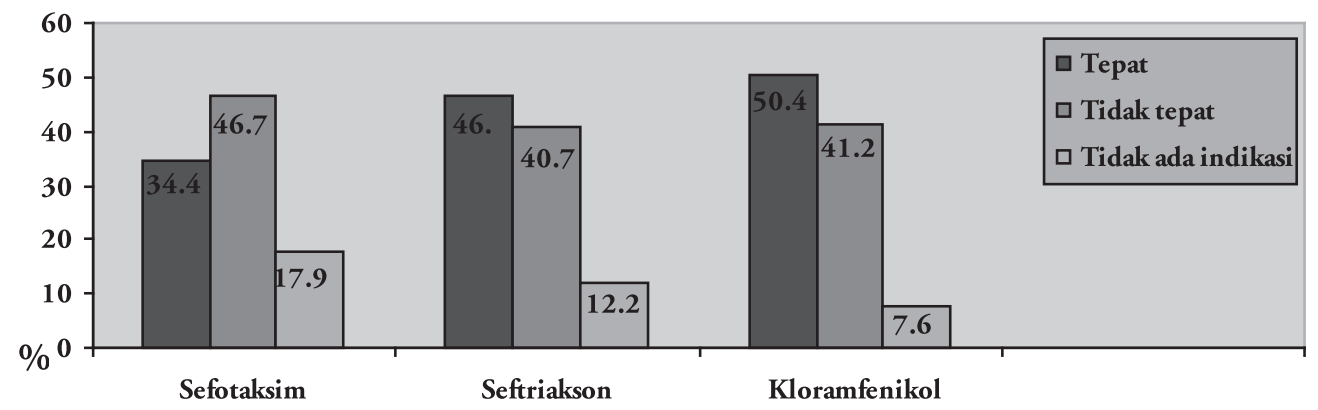

Gambar 3. Evaluasi kualitatif pada tiga antibiotik terbanyak.

nyata sehingga diganti dengan antibiotik sesuai dengan hasil kultur dan uji kepekaannya. Satu pasien pnemonia awalnya menggunakan dua antibiotik secara bersamaan, dari hasil kultur ditemukan bakteri sensitif dengan satu antibiotik dan resisten terhadap antibiotik lainnya, karena dalam pemantauan perkembangan klinis kurang baik, antibiotik yang resisten diganti sesuai dengan hasil uji sensitivitas. Satu pasien yang mendapat terapi definitif lainnya, antibiotik pertama resisten dan perjalanan klinis kurang memuaskan, kemudian diganti dengan antibiotik yang sesuai.

Pemberian antibiotik kotrimoksazol profilaksis diberikan pada satu pasien HIV AIDS yang mempunyai kadar CD4 rendah untuk mencegah terjadinya pneumocystis carini pneumonia.

\section{Pembahasan}

Di RS Penyakit Infeksi Sulianti Saroso Jakarta ditemukan $619(41,7 \%)$ pasien mendapat antibiotik selama perawatan. Penelitian Satari $\mathrm{dkk}^{2}$ melaporkan 49,2\% pasien mendapat antibiotik, dari semua pasien di ruang rawat Departemen Ilmu Kesehatan Anak RS Ciptomangunkusumo kelas II dan III. Pasien Bedah Anak dan pasien hematologi-onkologi 30,8\%, lebih dari sepertiga di antaranya mengalami febrile netropenia yang selalu mendapat antibiotik. Pada penelitian yang dilakukan di RS Sutomo Surabaya dan RS Kariadi Semarang, ${ }^{13} 84 \%$ pasien rawat inap termasuk pasien bedah/kebidanan dan ICU mendapat antibiotik. Perbedaan penggunaan antibiotik antara lain terlihat dari perbedaan pengambilan subjek penelitian. Subjek penelitian yang mencakup pasien bedah atau ICU terlihat lebih tinggi penggunaan antibiotik untuk tujuan terapeutik ataupun profilaksis.

Antibiotik paling banyak diberikan di RS Penyakit
Infeksi Sulianti Saroso adalah sefotaksim 37,3\%, seftriakson 22,9\%, kloramfenikol 15,9\%; sedangkan Satari $\mathrm{dkk}^{2}$ menemukan antibiotik terbanyak digunakan adalah sefotaksim $25,1 \%$, seftazidim $14,1 \%$, dan kotrimoksazol 11\%. Kami menemukan bakteri terbanyak adalah E.coli, S.epidermidis, sedangkan Satari menemukan bakteri terbanyak adalah S.epidermidis dan E.coli.

Melalui penilaian penggunaan antibiotik menurut Gyssens, kami menemukan 40,9\% antibiotik digunakan dengan tepat, lebih rendah dari penelitian lain 59\% pada pasien bedah dan non-bedah di sebuah rumah sakit univesitas di Wisconsin, ${ }^{3}$ lebih tinggi $21 \%$ dibandingkan penelitian AMRIN,${ }^{4}$ dan penelitian Hadi Usman ${ }^{13}$ di dua rumah sakit pendidikan. Penelitian lain di Thailand menemukan hanya 27/307 pasien yang menggunakan antibiotik dengan tepat. ${ }^{8}$

Penggunaan antibiotik yang tidak ada indikasinya ditemukan pada $14,4 \%$ pasien, jauh lebih tinggi 3,3\% dari penelitian Satari HI dkk. ${ }^{2}$ Dari penelitian AMRIN fase 1 tahun 2001-2002 didapat bahwa di Bagian Kesehatan Anak RS Kariadi Semarang, 46\% antibiotik diresepkan tanpa indikasi. ${ }^{4}$ Penelitian Usman $\mathrm{dkk}^{13}$ di RS Sutomo Surabaya dan di RS Kariadi Semarang ditemukan 32\% pemberian antibiotik dengan indikasi yang tidak jelas. Di Amerika Serikat, ditemukan 9\% antibiotik dinilai tidak perlu diberikan pada pasien karena tidak ada tanda infeksi. ${ }^{12}$ Pemakaian antibiotik yang tidak tepat yaitu yang sesuai dengan alur Gyssens II , III, dan IV ditemukan pada 43,8\% pasien, lebih kecil dari penelitian Aswaphoke ${ }^{8}$ di Bangkok Thailand yang menemukan $60 \%$ antibiotik penggunaannya tidak tepat. Pada penelitian Williamsen ${ }^{14}$ penggunaan antibiotik tidak tepat lebih sedikit $37,4 \%$.

Pada penggunaan sefotaksim, pemberian antibiotik yang tidak tepat $46,8 \%$ lebih banyak dibandingkan 
dengan penggunaan antibiotik tepat 34,4\%. Dari semua penggunaan sefotaksim, $22,7 \%$ tidak tepat oleh karena lamanya pemberian antibiotik yang terlalu singkat (Gyssens IIIb). Hal tersebut karena lama perawatan terbanyak $\leq 3$ hari $55,7 \%$ dan total yang dirawat $\leq 5$ hari $77,8 \%$.

Sebagian besar 99,4\% antibiotik diberikan secara empiris, karena mereka dirawat $\leq 5$ hari, dan pasien membaik kemudian pulang sebelum hasil kultur selesai.

Terapi definitif ditemukan hanya pada 4 pasien, sementara pemeriksaan kultur di RSPI Sulianti Saroso dilakukan pada $26,8 \%$ pasien rawat inap dan hasil kultur yang tumbuh bakteri $24,7 \%$. Pada penelitian Satari ${ }^{2}$ terapi definitif ditemukan pada $15,5 \%$ pasien dan pemeriksaan kultur dilakukan pada 38,5\% pasien.

Pemberian antibiotik secara profilaksis hanya ditemukan pada satu pasien HIV/AIDS, lebih rendah dari penelitian Satari $\mathrm{dkk}^{2}$ (8,4\%) dan sebagian besar mendapat antibiotik profilaksis kotrimoksazol. Kemungkinan ini karena 30,8\% pasien yang diamati adalah pasien hematologi-onkologi yang mendapat profilaksis kotrimoksazol yang sedang mendapat kemoterapi. Disamping itu, pengamatan juga termasuk pasien bedah anak yang mendapat antibiotik profilaksis. $\mathrm{Maki}^{3}$ melaporkan pemberian antibiotik profilaksis $30 \%$ pada pasien bedah dan non-bedah pada sebuah rumah sakit universitas di Wisconsin. Tampaknya pemberian antibiotik profilaksis terlihat lebih banyak pada penelitian di rumah sakit yang juga merawat pasien bedah.

Kelompok umur bayi paling banyak mendapat antibiotik 37, 8\%, sesuai penelitian Satari ${ }^{2}$. Kemungkinan ini karena bayi mempunyai angka kesakitan lebih tinggi dari kelompok umur yang lebih tua. Rata-rata lama rawat pasien adalah 3,7 hari, sesuai dengan penelitian Shankar $\mathrm{dkk}^{15}$ yang melaporkan median lama rawat empat hari yang sebagian besar pasien penelitiannya adalah gastroenteritis akut, sedangkan rata-rata lama rawat pasien pada penelitian Satari $\mathrm{dkk}^{2} 11$ hari, lebih dari $1 / 3$ subjek penelitiannya adalah pasien hemato-onkologi dengan lama rawat biasanya lebih panjang.

\section{Kesimpulan}

Pada evaluasi penggunaan antibiotik dengan menggunakan alur Gyssens di ruang rawat anak non- bedah
RSPI Sulianti Saroso, diberikan secara tepat 40,9\%, pemberian tidak tepat $43,8 \%$, dan pemberian tanpa indikasi $14,4 \%$. Sebagian besar terapi secara empirik $99,4 \%$, terapi definitif $0,5 \%$. Sefotaksim $37,3 \%$ paling banyak digunakan, sebagian besar digunakan tidak tepat $46,8 \%$ dan terbanyak disebabkan karena waktu pemberian obat yang terlalu singkat. Dengan hasil tersebut diperlukan pengawasan pemberian antibiotik yang lebih baik, tepat dan sesuai indikasi.

\section{Ucapan terima kasih}

Ucapan terima kasih disampaikan kepada staf Divisi Infeksi dan Penyakit Tropis Departemen Ilmu Kesehatan Anak FKUI, RSUP Ciptomangunkusumo, yang telah memberikan saran pada naskah ini.

\section{Daftar pustaka}

1. Iwan Darmansjah. Penggunaan antibiotik pada pasien anak. Maj Kedok Indon 2008; 58: 368-9.

2. Satari HI, Firmansyah A, Theresia. Qualitative evaluation of antibiotic usage in pediatric patients. Pediatr Indones 2011;51:303-309.

3. Maki DG. A study of antimicrobial misuse in a university hospital. Am J Med Sci 1978;275:271-82.

4. The AMRIN study group. Antimicrobial resistance, antibiotic usage and infection control: a self assessment program for Indonesia hospital. Jakarta; Direktorat Jendral Pelayanan Medis Kementrian Kesehatan RI; 2005.h.17-25.

5. Couper MR. Strategies for the rational use of antimicrobials. Clin Infect Dis 1997;24:154-6.

6. Thompson RL, Wrigt AJ. General principles of antimicrobial therapy. Mayo Clin Proc 1998;73:995-1006.

7. Yamileth M, Maria L, Avila AA, Maria AU, Ana LJ, Maria MP, dkk. Epidemiologi Obsevation of the judicious use of antibiotics in a paediatric teaching hospital. Int J Infect Dis 2002;6:74-7.

8. Nalinee A, Sribenja V, Richard FH. Pattern of antibiotic use in medical wards of a university hospital, Bangkok, Thailand. Oxford J 1990;12:136-41.

9. Gowan JE Jr. Antimicrobial resistance in hospital organism and its relation to antibiotic use. Rev Infect Dis 1983;5:1033-48.

10. WHO. Rational use of medicines. Media centre; 2010:1-4. 
11. Nouwen JL. Controlling antibiotic use and resistance. Clin Infect Dis 2006; 42:776-7

12. Gyssens IC. Audits for monitoring the quality of antimicrobial prescription. Dalam Van der Meer JW, Gould IM, penyunting. Antibiotic policies theory and practice. New York: Kluwer Academic; 2005.h.197226.

13. Hadi U, Duerink DO, Lestari ESl. Audit of antibiotic prescribing in two government teaching hospitals in
Indonesia. Clin Microbiol Infect 2008;14:698-707.

14. Willemsen I, Anneke G, Diana B, Ari S, Peter van K, Jan K. Appropriatness of antimicrobial therapy measured by repeated prevalence surveys. Antimicrob Agent Chem 2007;51: 864-7.

15. Shankar PR, Upadhyay DK, Subish P, Dubey AK, Mishra P. Prescribing pattern among paediatric inpatients in a teaching hospital in Western Nepal. Sin Med J 2006;47:261-5. 